390

JACkson, R. M. (1958). J. gen. Microbiol. 19, 390-401

\title{
Some Aspects of Soil Fungistasis
}

\author{
By R. M. JACKSON \\ Soil Microbiology Department, Rothamsted Experimental Station, \\ Harpenden, Hertfordshire
}

\begin{abstract}
SUMMARY: A series of fungi with varying degrees of sensitivity to soil fungistasis was selected as the result of agar disk and buried-slide tests with 17 fungi and one soil. Six out of $\boldsymbol{7}$ different soils exhibited a spectrum of inhibition of the test series of fungi similar to that of the first soil tested. The exception was a very acid raw humus soil which only inhibited the acid-sensitive fungus Acrostalagmus cinnabarinus. Fertilizer treatments of two series of plots at Rothamsted were found to affect soil fungistasis only through their influence on soil pH. Inhibitory effect decreased with increasing soil acidity, being absent from the most acid plot tested. From the results of experiments in which three fungi were pre-incubated before exposure to the influence of soil, it is suggested that spores are most sensitive to soil fungistasis at an early stage in the process of germination.
\end{abstract}

Reference was made in a previous paper (Jackson, 1958) to the numerous reports which suggest that factors which inhibit the germination of fungal spores and, to a lesser extent, the vegetative growth of fungi, are of widespread occurrence in the soil. Little is yet known of the properties and nature of the factors concerned. Dobbs \& Hinson (1953) demonstrated that a considerable range of different soils all produced fungistatic effects, but that subsoils were either less inhibitory than surface soils or without any effect. A strain of Bacillus macerans isolated from partially sterilized soil was shown by Park (1956) to possess the ability to digest fungal structures, to inhibit spore germination and to cause the production of distortions and sometimes chlamydospores by Fusarium roseum. In autoclaved soil the isolate produced toxic effects believed to be similar to those caused by fresh soil as observed by Neilson-Jones (1941) and Dobbs \& Hinson (1953). The work described in the present paper was conducted to elucidate some features of soil fungistasis and particularly to determine whether or not the inhibitory effect exhibited by quite different soils is due to the presence of similar or the same inhibitory substances.

\section{METHODS}

The agar disk technique. In this technique, which has been described previously (Jackson, 1958), disks of agar $7.5 \mathrm{~mm}$. in diameter by $1.5 \mathrm{~mm}$. in thickness are placed on filter-paper in contact with moist unsterile soil and surface inoculated with fungal spores. After a period of incubation, the disks are examined and the \% of germinated spores in 4 random fields on each of 4 replicate disks recorded. Before analysis the percentages are transformed to angular values. Control disks are incubated on moistened filter-paper in the absence of soil. As a standard procedure in the experiments described here, 
disks over soil and control disks were incubated for $1 \mathrm{hr}$. at $25^{\circ}$ after placing in contact with the filter-paper but before inoculation. The disks were prepared from agar composed of Bacto-peptone, 5.0 g.; Bacto-agar, 20.0 g.; distilled water, $1000 \mathrm{ml}$. The presence of peptone in the agar enhanced the germination of spores on control disks without interfering with the expression of fungistasis on disks over soil.

The buried slide technique. The technique used was based on that devised by Chinn (1953). Microscope slides, coated with a film of $2 \cdot 0 \%(w / v)$ agar $+0.5 \%$ $(w / v)$ peptone in which are suspended spores of the fungus being examined are buried in Petri dishes in $50 \mathrm{~g}$. fresh soil, brought to $c .60 \%$ of water-holding capacity with distilled water. After incubation for $42 \mathrm{hr}$. at $25^{\circ}$ the slides are removed, allowed to dry, and stained with acetic-aniline blue (Jones \& Mollison, 1948) before mounting in Euparal. One hundred spores in random microscope fields are counted and the number which have germinated recorded. Control slides also coated with spore suspensions in agar are incubated in Petri dishes over moist filter-paper and examined after $42 \mathrm{hr}$.

Soils. (1) Rothamsted I; Broadbalk field, Plot 2 (14 tons farmyard manure/ acre/year), clay loam with flints overlying chalk, $\mathrm{pH} 7 \cdot 2$. (2) Rothamsted II; fallow plot West of greenhouses, clay loam with flints overlying chalk, $\mathrm{pH} 6 \cdot 0$. (3) Sewell, Bedfordshire; chalk soil containing a high percentage of raw chalk and carrying a typical mixed calcicole flora; $\mathrm{pH}$ 7·3. (4) Barton-in-the-clay, Bedfordshire; clay containing some chalk from a weedy pasture consisting of Holcus, Agropyron, Trifolium, Ranunculus, etc.; pH 7•3. (5) Silsoe, Bedfordshire; sandy soil with high coarse sand fraction derived from the Lower Greensand and carrying a sparse cover including Cytisus, Ulex and mixed grasses; pH 4.9. (6) Rockingham, Northamptonshire; loam containing some free limestone overlying limestone from an arable field under barley; $\mathrm{pH} 6 \cdot 7$. (7) Charnwood Forest, Leicestershire; acid humus soil overlying granite with cover of Pteridium and Aira; pH 2.8. (8) Sedgebrook, Lincolnshire; clay soil overlying Keuper Marl from headland of arable field; $\mathrm{pH}$ 6.2. (9) Baston, Lincolnshire; silty loam fen soil from arable field under wheat; pH 7·3.

Fungi. The following fungi were used, all were isolated from soil the origin of which is given: Mucor sp. Rothamsted; Absidia sp., Rothamsted; Zygorhynchus sp., Barnet, Hertfordshire; Syncephalastrum sp., Rothamsted; Mortierella sp., Rothamsted; Penicillium citrinum, Thom, Ibadan, Nigeria; Penicillium sp. 1, Rothamsted; Penicillium sp. 2, Rothamsted; Paecilomyces marquandii (Massee) Hughes, Woburn, Bedfordshire; Gliocladium roseum (Link) Bain, Woburn; Acrostalagmus cinnabarinus Corda, Rothamsted; Cephalosporium sp., Rothamsted; Fusarium sp. 1, Rothamsted; Fusarium culmorum (W. G. Sm.) Sacc. Rothamsted; Oidiodendron sp., Barnet; Cladosporium herbarum Link, Barnet; Gliomastix convoluta (Harz) Mason, Barnet; Myrothecium sp., Woburn. 


\section{RESULTS}

\section{The fungistatic spectrum of Rothamsted soil}

When tested against a range of different micro-organisms, antibiotics usually produce a characteristic pattern or spectrum of inhibition as the result of differences in the sensitivities of the micro-organisms used. Since there were indications that fungi exhibit some degree of differential sensitivity towards soil fungistasis, it was considered of interest to determine the inhibitory spectrum of one soil against a range of fungi and then to compare this spectrum with those produced by other soils against fungi selected from the range.

The effect of Rothamsted I soil on the spore germination of 17 fungi was determined by the agar disk method and the buried-slide technique. On all the control slides which were incubated for $\mathbf{4 2} \mathrm{hr}$. in moist chambers the growth of fungal mycelium was too thick to allow an assessment of \% spore germination to be made, but inoculated disks placed on moist filter-paper in the absence of soil provided satisfactory controls for both tests. The $\%$ germination of spores of the fungi tested on agar disks over moist filter-paper (control), agar disks over soil and on slides buried in soil are shown in histogram form in Fig. 1. The fungi have been arranged as far as possible in decreasing order of sensitivity to Rothamsted I soil in the agar disk test. It can be seen that the fungi studied varied in their reaction to soil fungistasis; for example, the spores of Oidiodendron sp. and Syncephalastrum sp. were completely prevented from germinating in the presence of soil in both tests, whereas those of Fusarium culmorum and Gliocladium roseum were not visibly affected by soil on agar disks, but were inhibited on buried slides. Buried slides were found to provide a much more sensitive test for soil fungistasis than agar disks, as might be expected from the greater proximity to the soil of spores on buried slides as compared with agar disks over soil. In the experiment for which results are given, germination of the spores of only 7 of the test fungi was observed on buried slides, while spores of 13 out of the total of 17 fungi tested showed some germination on agar disks. With one exception (Zygorhynchus sp.), the fungi which showed some germination on buried slides were not significantly inhibited on agar disks over soil. Although 87 out of 100 conidia of Fusarium sp. 1 germinated on slides buried in soil, in every case the short germ tubes produced terminated in typical thick-walled aseptate or uniseptate chlamydospores. This behaviour was never observed on agar disks over soil nor in the controls. $\boldsymbol{F}$. culmorum behaved in a different manner, germination on slides in contact with soil being reduced to $2 \%$ with no indication of chlamydospore production. The phenomenon of chlamydospore production by certain isolates of Fusarium in the presence of soil is being further studied.

\section{Comparison of the fungistatic spectra of different soils}

In order to compare the fungistatic spectra of a number of different soils the following fungi were chosen from those tested against Rothamsted I soil as forming a convenient test series: Oidiodendron sp.; Penicillium sp. 2; 
Acrostalagmus cinnabarinus; Cladosporium herbarum; Gliomastic convoluta; Paecilomyces marquandii; Fusarium culmorum and, in addition, Penicillium citrinum, which had previously been used as a standard test organism (Jackson, 1958). The sensitivity of these fungi to 7 different soils was measured by the agar-disk method; the tests were all carried out on the same day and
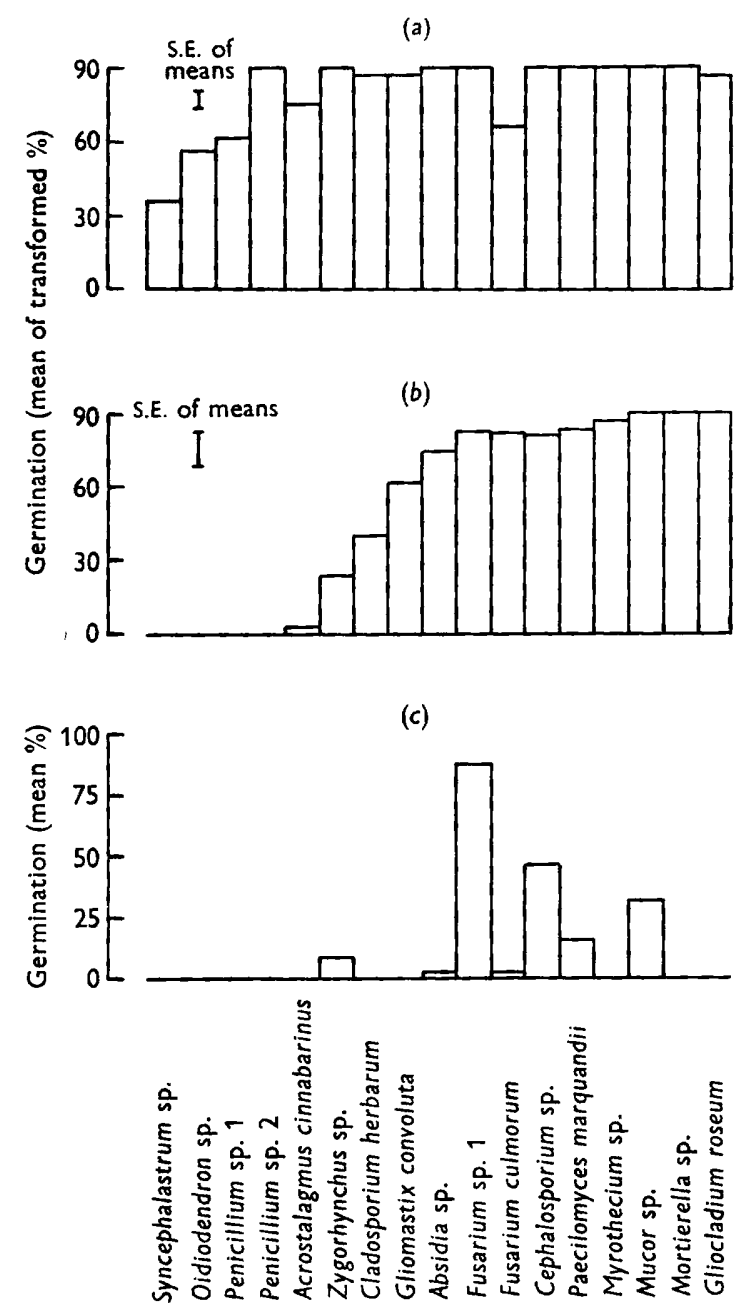

Fig. 1. Spore germination of 17 fungi: (a) on agar disks in the absence of soil; $(b)$ on agar disks over soil; $(c)$ on slides buried in soil. (Standard errors of means for $(a)$ and $(b)$ at $P=0 \cdot 05$.)

within a week of collecting the samples. Before testing, the moisture content of each sample was brought up to $c .60 \%$ of water holding capacity with distilled water. Inspection of the results of this experiment, which are presented as a histogram in Fig. 2, reveals that, with the exception of soil no. 5, all the soils have a very similar spectrum of inhibition with respect to the 8 test fungi. 
The soil which did not show a spectrum similar to that of the others was the very acid ( $\mathrm{pH} \mathrm{2 \cdot 8)}$ raw humus soil from Charnwood Forest; over this soil only one fungus, Acrostalagmus cinnabarinus, was significantly inhibited.

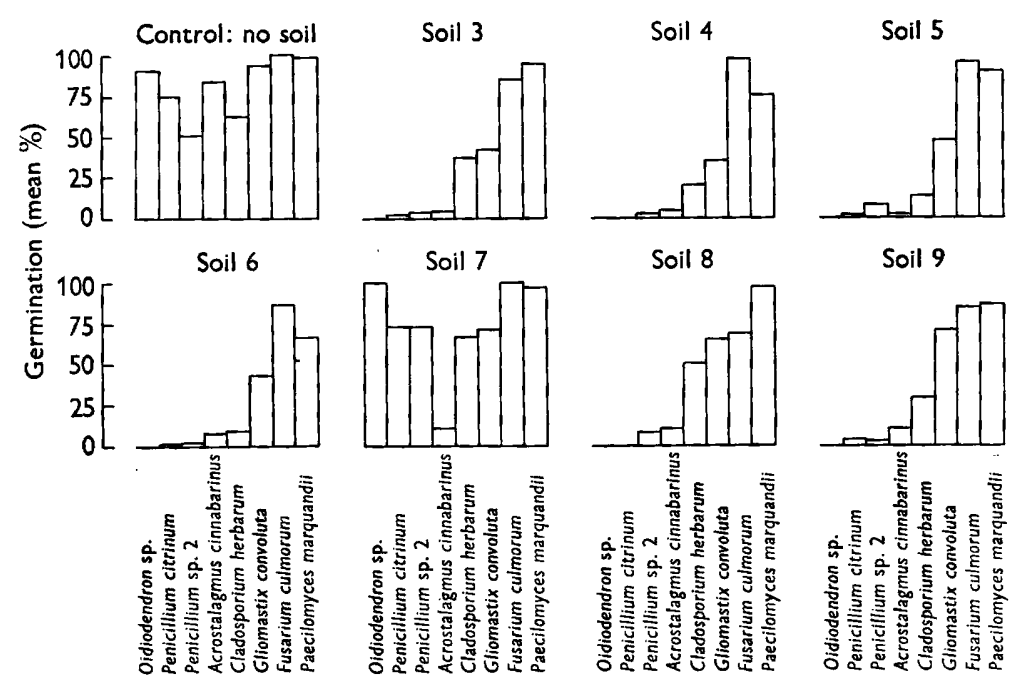

Fig. 2. Spore germination of the test series of fungi on agar disks in the absence of soil, and over 7 different soils.

\section{Sensitivity of the test fungi to $\mathrm{pH}$ value}

In view of the possible direct effect of soil $\mathrm{pH}$ value on the germination of the test fungi, tests were made using the agar-disk method to determine the effect on the germination of the test fungi of a range of McIlvaine's citric acid +sodium phosphate buffer solutions (Britton, 1955), $\mathrm{pH} 3 \cdot 0-8 \cdot 0$. The filter-papers on which the agar disks were placed were moistened with the appropriate buffer solutions. The results of the tests (Fig. 3) show considerable differences in the effect of $\mathrm{pH}$ value on the germination of the test fungi. It was found, as might be expected, that the $\mathrm{pH}$ value of a soil had much less effect on the germination of fungal spores in the agar disk test than a buffer solution of similar $\mathrm{pH}$. In the tests on different soils, the germination of only one fungus, Acrostalagmus cinnabarinus, was limited by the unfavourable $\mathrm{pH}$ of the acid raw humus soil (no. 7).

\section{Fungistasis in Park Grass and Broadbalk plots}

The classical fields at Rothamsted, the crop and fertilizer histories of which have been recorded for the past hundred years, afford a unique opportunity of studying the effects of different treatments over a long period on the fungistatic activity of soils which were originally similar. The Park Grass permanent grass plots are of particular interest since the fertilizer treatments applied have resulted in large $\mathrm{pH}$ differences between the plots with associated changes in the vegetation and nature of the soil. Composite soil samples were taken from 
the upper $10 \mathrm{~cm}$. of selected Park Grass plots and tested for fungistasis by the agar-disk method using Penicillium citrinum as test organism. Details of the plots sampled and the results obtained are given in Table 1. A striking feature of the results is the correlation between soil $\mathrm{pH}$ and inhibitory activity, strong

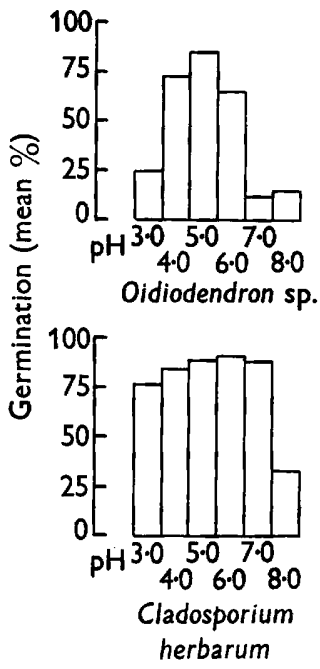

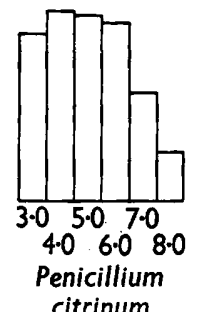

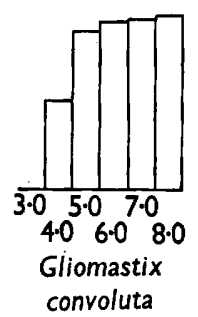

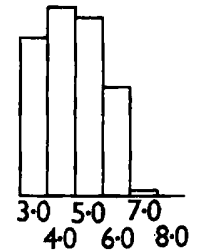

Penicillium sp. 2

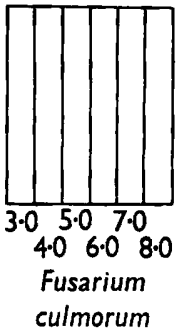

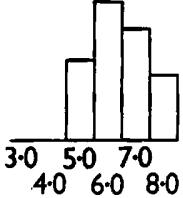

Acrostalagmus cinnabarinus

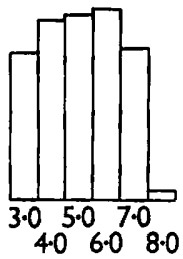

Paecilomyces marquandii

Fig. 3. Spore germination of the test series of fungi on agar disks over MeIlvaine's buffer solutions.

Table 1. The germination of Penicillium citrinum conidia on agar disks over soil from Park Grass plots

\begin{tabular}{|c|c|c|c|c|}
\hline Plot no. & Treatment & $\mathrm{pH}$ value & $\begin{array}{c}\text { Mean \% } \\
\text { germination }\end{array}$ & $\begin{array}{c}\text { Mean } \\
\text { transfor } \\
\% \text { germin }\end{array}$ \\
\hline $\mathbf{3}$ & No manure, lime & 6.9 & o & o \\
\hline 7 & $\mathbf{P}, \mathbf{K}, \mathbf{N a}, \mathbf{M g}$ & $4 \cdot 5$ & $55 \cdot 7$ & 48 \\
\hline $7 \mathbf{a}$ & $\mathbf{P}, \mathbf{K}, \mathrm{Na}, \mathbf{M g}$, lime & $6 \cdot 4$ & $6 \cdot 4$ & \\
\hline $11_{1}$ & $\mathbf{N}, \mathbf{P}, \mathbf{K}, \mathbf{N a}, \mathbf{M g}$ & $3 \cdot 0$ & $82 \cdot 7$ & 65 \\
\hline $11_{1} a$ & $\mathbf{N}, \mathbf{P}, \mathbf{K}, \mathbf{N a}, \mathbf{M g}$, lime & $4 \cdot 3$ & $57 \cdot 2$ & 49 \\
\hline 12 & No manure & $5 \cdot 2$ & 10.7 & 18 \\
\hline 13 & Dung, fish guano & $4 \cdot 1$ & $61 \cdot 2$ & \\
\hline $13 \mathbf{a}$ & Dung, fish guano, lime & $6 \cdot 4$ & $\mathbf{1 1} \cdot \mathbf{5}$ & 19 \\
\hline 7 & As 7 above, autoclaved $\dagger$ & $5 \cdot 0$ & $100 \cdot 0$ & \\
\hline $\mathbf{3}$ & As 3 above, autoclaved $\dagger$ & $6 \cdot 9$ & $100 \cdot 0$ & \\
\hline lter-paper & & & $88 \cdot 7$ & \\
\hline
\end{tabular}

\footnotetext{
N Ammonium sulphate 6 cwt.

P Superphosphate $3 \frac{1}{2}$ cwt.

K Potassium sulphate $4 \frac{1}{2}$ cwt. per acre per year

$\mathrm{Na}$ Sodium sulphate $1 \mathrm{cwt}$.

Mg Magnesium sulphate 1 cwt.

Lime 18 cwt. per acre every 4 years

$\left.\begin{array}{ll}\text { Dung } & 14 \text { tons } \\ \text { Fish guano } & 6 \text { cwt. }\end{array}\right\}$ per acre every four years

* Significant difference between means for $P=0 \cdot 05$ is $5 \cdot 8$.

$\dagger 15 \mathrm{lb}$./sq.in. for $30 \mathrm{~min}$.
}

Mean of Mermed o 48.4 14.4 $65 \cdot 6$ $49 \cdot 3$ $18 \cdot 8$ $51 \cdot 6$ $19 \cdot 5$

90.0 $90 \cdot 0$ $70 \cdot 2$ 
inhibitory effects being associated with a high $\mathrm{pH}$ and weak effects with a low $\mathrm{pH}$ value. In each of the pairs of plots receiving lime and no lime, the limed soils produced the greater inhibition. With the most acid plot (plot $11_{1}$ ) germination of $\boldsymbol{P}$. citrinum conidia did not differ significantly from that of the filter-paper control. That the large differences in germination obtained with soils of different $\mathrm{pH}$ values was not due directly to the effect of $\mathrm{pH}$ value on the spores was confirmed in the tests with autoclaved soil from plots 7 and 3; $100 \%$ germination occurred with both of these soils with $\mathrm{pH}$ values (after autoclaving) of 5.0 and 6.9 , respectively. In this experiment $\mathrm{pH}$ differences between the plots obscured any effects which manurial treatments might have exerted on fungistasis.

Table 2. The germination of Penicillium citrinum conidia on agar disks over soil from Broadbalk plots

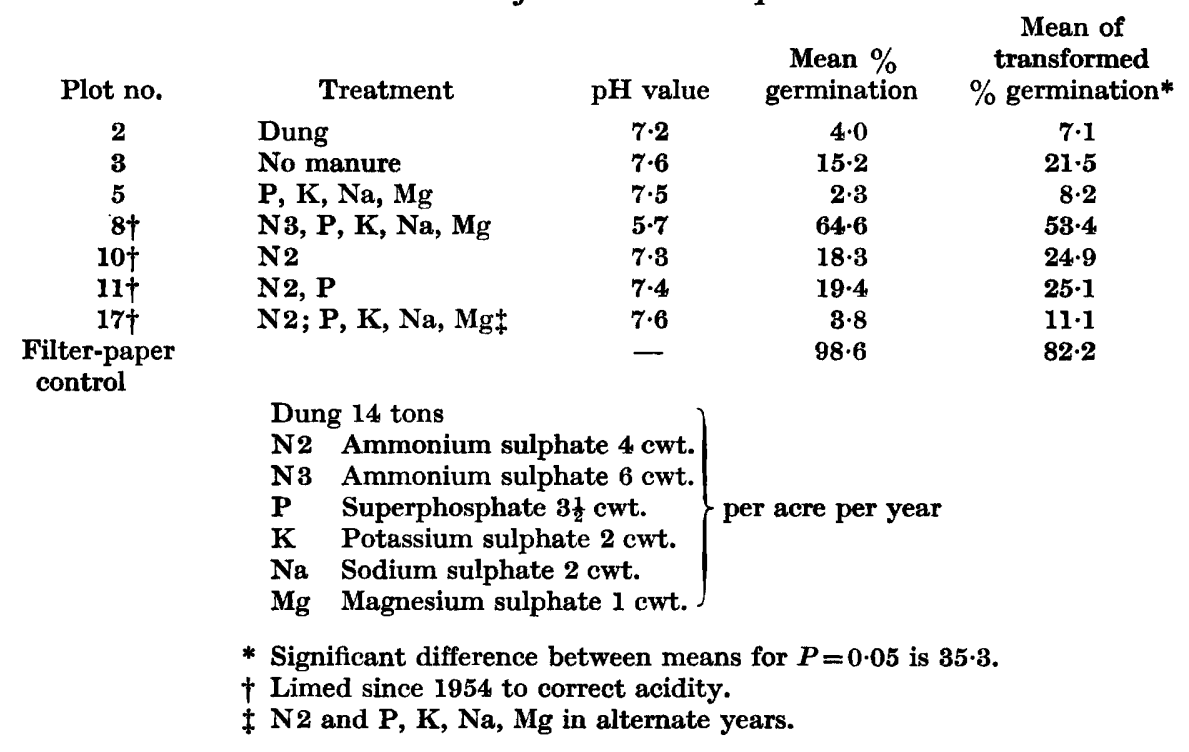

On Broadbalk permanent wheat field, differences in $\mathrm{pH}$ values between plots due to different fertilizer treatments have been decreased since 1954 by liming the plots receiving ammonium sulphate. With the exception of plot 8 (pH 5.7), all the plots sampled had $\mathrm{pH}$ values between $\mathbf{7 \cdot 2}$ and $7 \cdot 6$, although receiving different fertilizer treatments. The results of the agar-disk tests are shown in Table 2. A rather high standard deviation in the results indicates the uneven distribution of the inhibitory factor in the soil of the plots tested. Least inhibition occurred over the most acid soil, receiving the heaviest applications of ammonium sulphate, but no significant differences between the germination of Penicillium citrinum conidia on disks over the soils from the other plots was detected despite the differences in treatment. 
The effect of delayed exposure to soil upon spore germination and subsequent development of fungi

After the agar disks are placed in contact with the filter-paper in the agardisk test, it must be assumed that a delay occurs before a sufficient quantity of the inhibitory factor diffuses into the disks to prevent germination. This assumption is supported by the observation that a delay in inoculating the disks after they have been placed in position over the soil decreases the

Table 3. The effect of delaying the exposure to soil fungistasis of germinating Penicillium citrinum conidia on agar disks

\begin{tabular}{|c|c|c|c|c|}
\hline $\begin{array}{l}\text { Duration of } \\
\text { incubation } \\
\text { over filter- } \\
\text { paper (hr.) }\end{array}$ & $\begin{array}{l}\text { Condition on trans- } \\
\text { ferring to soil }\end{array}$ & $\begin{array}{l}\text { Duration of } \\
\text { incubation } \\
\text { over soil } \\
\text { (hr.) }\end{array}$ & $\begin{array}{l}\text { Condition at end of } \\
\text { incubation }\end{array}$ & $\begin{array}{l}\text { Final \% } \\
\text { germination } \\
\text { (mean) }\end{array}$ \\
\hline 0 & - & 24 & $\begin{array}{l}\text { Unswollen, ungerminated } \\
\text { conidia and germinated } \\
\text { conidia with well-de- } \\
\text { veloped normal germ } \\
\text { tubes }\end{array}$ & $12 \cdot 1$ \\
\hline 4 & $\begin{array}{l}\text { No germination or } \\
\text { swelling }\end{array}$ & 20 & $\begin{array}{l}\text { Well-developed germ } \\
\text { tubes with penicillus } \\
\text { formation starting }\end{array}$ & $74 \cdot 7$ \\
\hline 8 & $\begin{array}{l}\text { Some conidia swollen } \\
\text { and } c .10 \% \text { germi- } \\
\text { nated }\end{array}$ & 16 & $\begin{array}{l}\text { Well-developed branching } \\
\text { hyphae with many } \\
\text { penicilli-bearing conidia }\end{array}$ & 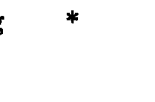 \\
\hline 16 & $\begin{array}{l}\text { c. } 90 \% \text { germination and } \\
\text { well-developed germ } \\
\text { tubes }\end{array}$ & 8 & $\begin{array}{l}\text { Well-developed branching } \\
\text { hyphae with many } \\
\text { penicilli-bearing conidia }\end{array}$ & 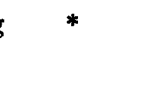 \\
\hline 24 & - & 0 & $\begin{array}{l}\text { Thick matted mycelial } \\
\text { growth with frequent } \\
\text { conidial heads but less } \\
\text { abundant than above }\end{array}$ & * \\
\hline
\end{tabular}

* High percentage germination but hyphal development made a count impossible.

number of spores which germinate. This effect may also be examined, as in the following experiment, by allowing the spores of the test fungus to begin germination before subjecting them to the influence of the soil. Sixteen disks of peptone agar were placed in a Petri dish on filter-paper moistened with distilled water and inoculated with a suspension of Penicillium citrinum conidia. After $4 \mathrm{hr}$. incubation, 4 disks were examined and subsequently placed on filter-paper squares in contact with moistened Rothamsted I soil. After another $4 \mathrm{hr}$., a further set of 4 disks was similarly treated. As controls, one set of 4 disks remained on the filter-paper and another set was kept over soil for the duration of the experiment. Twenty-four hr. from the beginning of the experiment all the disks were removed and examined. The results, which are summarized in Table 3 , show that a large increase in germination as compared with the soil control resulted from incubation for $4 \mathrm{hr}$. before placing the disks over soil, even though no visible changes had occurred in the spores 
by the end of the $4 \mathrm{hr}$. period. After $8 \mathrm{hr}$. of pre-incubation followed by $16 \mathrm{hr}$. over soil, vegetative development had taken place to an extent comparable to the control without soil; however, conidiophore and conidium production was more abundant on the disks transferred to soil than on those remaining on filter-paper. The fungus behaved similarly on disks pre-incubated for $16 \mathrm{hr}$. before being transferred to soil for a further $8 \mathrm{hr}$. of incubation.

Further experiments on the effect of pre-incubating spores before subjecting them to the influence of soil fungistasis were made by the buried-slide technique with the two fungi Gliocladium roseum and Paecilomyces marquandii.

Table 4. The effect of delaying the exposure of germinating Gliocladium roseum conidia to soil fungistasis

\begin{tabular}{|c|c|c|c|c|}
\hline $\begin{array}{l}\text { Duration of } \\
\text { incubation } \\
\text { in moist } \\
\text { chamber } \\
\text { (hr.) }\end{array}$ & $\begin{array}{l}\text { Condition on } \\
\text { transferring to soil }\end{array}$ & $\begin{array}{c}\text { Duration of } \\
\text { incubation } \\
\text { in soil } \\
(\mathrm{hr} .)\end{array}$ & $\begin{array}{l}\text { Condition at end of } \\
\text { incubation }\end{array}$ & $\begin{array}{l}\text { Final } \% \\
\text { germination }\end{array}$ \\
\hline o & - & 48 & No germination or swelling & $\mathbf{0}$ \\
\hline $\mathbf{3}$ & $\begin{array}{l}\text { No germination or } \\
\text { swelling }\end{array}$ & 45 & No germination or swelling & $\mathbf{0}$ \\
\hline 6 & $\begin{array}{l}\text { No germination or } \\
\text { swelling }\end{array}$ & 18 & $\begin{array}{l}\text { Germinated conidia un- } \\
\text { evenly distributed }\end{array}$ & c. 4 \\
\hline 22 & $\begin{array}{l}\text { c. } 100 \% \text { germination, } \\
\text { long germ tubes }\end{array}$ & 26 & $\begin{array}{l}\text { Well-developed interwoven } \\
\text { hyphae }\end{array}$ & c. 100 \\
\hline 24 & - & 0 & Well-developed germ tubes & c. 100 \\
\hline 48 & - & 0 & $\begin{array}{l}\text { Well-developed interwoven } \\
\text { hyphae }\end{array}$ & c. 100 \\
\hline
\end{tabular}

Germination of the conidia of these fungi is not normally inhibited to a significant extent on agar disks over soil but is inhibited on buried slides. Rothamsted II soil was used in these buried slide experiments. The treatments and results of the experiments with $G$. roseum and $\boldsymbol{P}$. marquandii are summarized in Tables 4 and 5. Both fungi responded to the treatments in a very similar manner. With up to $48 \mathrm{hr}$. of incubation in soil, or with $3 \mathrm{hr}$. pre-incubation followed by $45 \mathrm{hr}$. in soil, no visible changes occurred in the conidia of either fungus. With pre-incubation for $6 \mathrm{hr}$. before $18 \mathrm{hr}$. in soil, a small $\%$ of the conidia of both fungi had germinated although they were apparently unchanged when transferred to soil. The uneven distribution of germinated conidia on the slides following this treatment was more marked with $P$. marquandii than with $G$. roseum, but was evident with both fungi. After pre-incubation for $22 \mathrm{hr}$. both fungi had germinated well, but with $P$. marquandii differences were apparent in the final growth of the fungus between those slides which remained in moist chambers for the remainder of the $48 \mathrm{hr}$. period and those which were transferred to soil. Vegetative development of $P$. marquandii after burial in soil was considerably less than on slides which remained in the moist chamber, but phialides were more frequent and better developed. 
Table 5. The effect of delaying the exposure of germinating

Paecilomyces marquandii conidia to soil fungistasis

\begin{tabular}{|c|c|c|c|c|}
\hline $\begin{array}{c}\text { Duration of } \\
\text { incubation } \\
\text { in moist } \\
\text { chamber } \\
\text { (hr.) }\end{array}$ & $\begin{array}{l}\text { Condition on } \\
\text { transferring to soil }\end{array}$ & $\begin{array}{l}\text { Duration of } \\
\text { incubation } \\
\text { in soil } \\
\text { (hr.) }\end{array}$ & $\begin{array}{l}\text { Condition at end of } \\
\text { incubation }\end{array}$ & $\begin{array}{l}\text { Final \% } \\
\text { germination }\end{array}$ \\
\hline 0 & - & 48 & No germination or swelling & 0 \\
\hline 3 & $\begin{array}{l}\text { No germination or } \\
\text { swelling }\end{array}$ & 45 & No germination or swelling & $\mathbf{0}$ \\
\hline 6 & $\begin{array}{l}\text { No germination or } \\
\text { swelling }\end{array}$ & 18 & $\begin{array}{l}\text { Germinated conidia con- } \\
\text { centrated in certain areas, } \\
\text { short germ tubes }\end{array}$ & c. $\mathbf{3}-\mathbf{2 0}$ \\
\hline 22 & $\begin{array}{l}\text { c. } 90 \% \text { germination } \\
\text { well-developed germ } \\
\text { tubes }\end{array}$ & 26 & $\begin{array}{l}\text { Well-developed hyphae } \\
\text { with frequent single or } \\
\text { grouped phialides and } \\
\text { conidial chains }\end{array}$ & c. 100 \\
\hline 24 & - & 0 & Well-developed germ tubes & c. 90 \\
\hline 48 & - & $\mathbf{0}$ & $\begin{array}{l}\text { Well-developed interwoven } \\
\text { hyphae, a few phialides } \\
\text { present }\end{array}$ & \\
\hline
\end{tabular}

The comparison made when testing the response of a range of fungi to Rothamsted I soil between the behaviour of fungal spores on buried agarcoated slides and agar disks on filter-paper in contact with soil emphasizes that the latter method provides the more sensitive test for fungistasis. However, when the relative sensitivities of a number of fungi are being determined, or the inhibitory spectra of different soils compared, the smaller sensitivity of the agar disk method has certain advantages. On buried slides in Rothamsted I soil only $\mathbf{7}$ out of $\mathbf{1 7}$ fungi tested showed any germination, and of these, 3 gave $<10 \%$ germination and one of the fusaria produced chlamydospores. On agar disks, on the other hand, 13 of the fungi tested germinated and it was possible to select from these a suitable test series.

The results of the tests on different soils with test series of fungi, in which similar spectra of inhibition were obtained from 6 of 7 soils, strongly suggest that identical or very similar factors or combinations of factors are operative as inhibitors of germination. If it should prove that combinations of inhibitory substances are responsible for soil fungistasis, the similarity of spectra from different soils makes it seem likely that the mixture would be a simple one with few components. The marked specificity shown towards the test fungi suggests that the inhibitor or inhibitors are complex organic substances, probably of microbial origin. Lack of inhibition of all the test fungi, except Acrostalagmus cinnabarinus by the very acid raw humus soil from Charnwood Forest, is in agreement with the results from the acid Park Grass plots.

The most significant finding in the experiments with soil from Park Grass and Broadbalk plots was the decrease in fungistatic effect with increasing soil acidity. Whether this was due to lack of production of the factor in acid soils 
(possibly resulting from reduction in the numbers or absence of the producing organisms) or to relative biological inactivity under acid conditions such as might be shown by a basic compound, is not clear.

Two points of interest emerge from the experiments on the pre-incubation of spores before subjecting them to soil fungistasis. In the experiment with agar disks and Penicillium citrinum the results obtained suggest that even before visible changes have occurred in germinating conidia in the absence of an inhibitor, a stage may be reached at which normally inhibitory concentrations of the fungistatic factor fail to prevent completion of germination. As noted above, some delay is to be expected after placing a disk on filterpaper over soil before the diffusion into the upper part of that disk of an effective concentration of factor. The condition of spores on an agar disk when transferred to soil after a period of pre-incubation may not correspond to their condition at the time when the fungistatic factor begins to be effective. When buried slides are used to test the effect of soil fungistasis, on the other hand, the equilibrium concentration of inhibitor would be reached much sooner. Germination of a small percentage of conidia of both Gliocladium roseum and Paecilomyces marquandii on slides incubated for $6 \mathrm{hr}$. in a moist chamber followed by $18 \mathrm{hr}$. in soil, confirms the results obtained with Penicillium citrinum on agar disks and again suggests that spores are most sensitive to fungistasis at an early stage in the process of germination. With this technique also the spores had not visibly changed at the time of transfer.

Both Penicillium citrinum on agar disks and Paecilomyces marquandii on buried slides showed some increase in reproductive activity and a decrease in vegetative activity when transferred to soil after germination had started, as compared with disks or slides incubated for the whole period in the absence of soil. Although this shift in activity should not necessarily be attributed to an effect of the fungistatic factor, the possibility cannot be ignored. Christensen \& Davies (1940) found that a toxic substance produced by Bacillus mesentericus would suppress growth, inhibit or retard spore germination and increase conidial production in Helminthosporium sativum. It is probable that the effects on fungi of biologically active factors present in the soil will be complex, producing reactions dependent on the stage of growth of the fungus, the concentration of the factor and the environmental conditions.

The author wishes to thank Dr H. G. Thornton, For.Sec.R.S., for his helpful criticism and encouragement, Miss Ann Oliver for technical assistance and Miss Mabel Dunkley for preparing the typescript. This work forms part of a thesis presented for the Ph.D. degree of the University of London.

\section{REFERENCES}

Britton, H. T. S. (1955). Hydrogen Ions, vol. I, 4th ed. London: Chapman and Hall Ltd.

Chinn, S. H. F. (1953). A slide technique for the study of fungi and actinomycetes in soil with special reference to Helminthosporium sativum. Canad. J. Bot. 31, 718. 
Christensen, J. J. \& Davies, F. R. (1940). Variation in Helminthosporium sativum induced by a toxic substance produced by Bacillus mesentericus. Phytopatho$\log y, 30,1017$.

Dosbs, C. G. \& Hinson, W. H. (1953). A widespread fungistasis in the soil. Nature, Lond. 172, 197.

JACKson, R. M. (1958). An investigation of fungistasis in Nigerian soils. $J$. gen. Microbiol. 18, 248.

Jones, P. C. T. \& Mollison, J. E. (1948). A technique for the quantitative estimation of soil micro-organisms. J. gen. Microbiol. 2, 54.

NeILson-Jones, W. (1941). Biological aspects of soil fertility. J. agric. Sci. $31,379$.

PARK, D. (1956). Effect of substrate on a microbial antagonism, with reference to soil conditions. Trans. Brit. mycol. Soc. 39, 239.

(Received 16 April 1958) 